\title{
Arredor do Rexurdimento. Apuntamentos xerais
}

\author{
Arround the Rexurdimento. General Notes
}

\author{
Xurxo Martínez GonzÁlez \\ xurxomartinezglez@gmail.com \\ Concello de Redondela / Universidade de Vigo
}

Resumo: Este é un estudo do actual estado da investigación sobre o Rexurdimento. A partir dunha bibliografía actualizada, analizamos a renacenza galega e facemos a nosa achega en canto á definición, cronoloxía, características centrais, contribución ao imaxinaio nacional colectivo e o valor da lingua como elemento central na construción da identidade e criterio filolóxico na literatura. Ademais, o estudo parte da relación entre o campo político e o cultural. Para isto tomamos de base, e de xeito principal, os estudos de Xoán González Millán, Antón Figueroa e Alejandro Alonso Nogueira.

Paraules clau: Rexurdimento, criterio filolóxico, lingua galega, imaxinario nacional colectivo, provincialismo

\begin{abstract}
This is a study of the current state of the Rexurdimento's research. Based on an updated bibliography, we analyze de galician renaissance and make our contribution in terms of definition, chronology, central characteristics, contribution to the national colectiva imaginary and the valeu of language as ca entral element in the constrution of identity and philological criteria in literatura. The study is based on the relationship between the political and cultura fields. We take, mainly, the Xoán González-Millán, Antón Figueroa and Alejandro Alonso Nogueira's studies.
\end{abstract}

Keywords: Rexurdimento, philological criteria, galician language, collective national imagery, provincialism 


\section{Introdución}

No pasado 2019 Anxo Angueira, presidente da Fundación Rosalía de Castro e profesor da Universidade de Vigo, publicaba o ensaio Rexurdimento. A palabra e a idea. Un libro que cuestiona o tratamento tradicional da literatura decimonónica tanto no concepto coma na periodización e mesmo na súa pertinencia para referirse ao fenómeno cultural e literario do XIX.

O certo é que na investigación político-cultural non existe unanimidade sobre o Rexurdimento. Hai propostas que diverxen na cronoloxía, na interpretación dos textos (un caso paradigmático é a recente revisión da obra de Rosalía de Castro (Álvarez, Angueira, Rábade e Vilavedra 2014) ou na lectura en clave política da produción cultural. Tamén se perciben escasas indagacións nos estudos comparativos con outros procesos análogos (nomeadamente a Renaixença), ${ }^{1}$ análises na liña da socioloxía da cultura ou unha visión máis integradora doutras expresións culturais como a música e a pintura. ${ }^{2}$

Neste artigo ofreceremos apenas unha panorámica para poñer ao día a cuestión rexurdimentista. Para isto citaremos varia bibliografía recente á vez que anotaremos propostas de liñas investigadoras que consideramos pertinentes e unha interpretación propia do Rexurdimento.

Xoán González-Millán é un dos principais teóricos dos estudos socioculturais galegos. A súa obra devén, na nosa opinión, nun referente inexcusable para tratar o século XIX, na medida en que nos fornece de aparellos analíticos moi útiles, moi rendibles, na investigación oitocentista. Por isto, o volume Resistencia cultural e diferencia histórica (2000) tórnase nun verdadeiro manual para a boa investigación. Este exemplar concentra o groso do artiluxio teórico de González-Millán que se completa coa publicación de artigos académicos.

Un trazo que define a súa obra investigadora, interrompida por un accidente mortal de tráfico en 2002, é a aceptación e práctica dun estudo multidisciplinar da cultura. Por esta causa, e dende unha base marxista, incorpora enfoques pouco habituais nos estudos galegos: a conformación dos (contra)espazos públicos, o concepto de hexemonía, a elaboración de estratexias de resistencia, a experiencia da subalternidade ou a aplicación da socioloxía da cultura.

1 Vid. Martínez González (2014; 2015).

2 Unha radiografía parcial destas lagoas investigadoras témolas en Alonso Nogueira (1999). Ademais debemos engadir a necesidade de redactar a «historia literaria» fronte aos modelos de «historia da literatura»e as análises unicamente textualistas, conforme a distinción feita por Desiré Nisard (1844). A primeira será unha lectura histórica da vida literaria (autores, obras, imprentas, crítica literaria, distribución...) en diálogo coa época histórico-política; a segunda, ten un sentido máis restritivo, centrando en criterios (estéticos, morais, relixiosos ou doutro tipo) a selección dos textos. 
En relación con estas liñas atopamos outras achegas relevantes en Antón Figueroa (1988; 2001), moi influído por Pierre Bordieu, coma González-Millán; ou do grupo Galabra da Universidade de Santiago de Compostela, que aplica a teoría dos polisistemas de Even-Zohar. ${ }^{3}$

Por último, queremos destacar o vieiro investigador de Alejandro Alonso Nogueira, discípulo directo e continuador do camiño aberto por González-Millán. Malia non ter publicada a súa tese de doutoramento (Intelectuales, lenguas y dialectos en la España del siglo XIX, 2015), podemos achegarnos á lectura crítica do oitocentos, cun ollo posto no campo político-cultural galego, atraveso da súa articulística investigadora $(1999 ; 2009)$.

\title{
2. Marco de estudo
}

Nos manuais de estudo escolar, o alumnado aprende que o Rexurdimento foi un período de restitución do idioma galego en canto ao seu uso literario. ${ }^{4}$ A recuperación é resultado dunha defensa consciente, mantida por unha parte da elite ilustrada, do prestixio e validez da lingua galega. Esta concepción do Rexurdimento atópase en Carballo Calero (1975), Carme Hermida (1992) ou Justo Beramendi (2007). Velaquí, pois, a tese tradicional sustentada por parte da investigación académica e institucionalizada por medio da escola.

Polo tanto, a percepción xeneralizada do Rexurdimento céntrase no aspecto literario (nin tan sequera cultural) e lingüístico. Pola contra, esta concepción resta todo o poder subversivo que nós observamos na medida en que foi unha estratexia de resistencia ante un marco dominante, como era a cultura española ligada á construción do novo sistema liberal español, que viviu con intensidade e recorrencia o debate territorial durante todo o XIX. O Rexurdimento impugnou o campo dominante dende un espazo contrahexemónico e contradiscursivo que acabaría en conflito político-cultural, como relataremos despois na polémica sostida por Manuel Murguía e Emilia Pardo Bazán.

Antón Figueroa (2001: 13-14) escribe sobre o caso:

\begin{abstract}
Se pensamos un pouco a historia da literatura galega a partir do Rexurdimento, poderiamos en termos moi aproximados e hipotéticos propoñer o seguinte: a producción literaria galega en galego xorde estreitamente vinculada a unhas tomas de posición políticas, tomas de posición heterodoxas no campo político español, na medida en que, cun enfoque rexionalista ou nacionalista, reclamaban unha certa autonomía política. Ó mesmo tempo, as tomas de posición implicadas polos textos literarios participaban deste carácter político pola súa temática, mais
\end{abstract}

\footnotetext{
3 Para unha aproximación a estas investigacións, vid. Lourido (2014).

4 O galego era a lingua oral e habitual de máis do 85 \% da poboación (Monteagudo 1999: 330) dentro dunha cidadanía maioritariamente analfabeta (na altura de 1887 era o 75\% no caso dos homes, 89\% as mulleres; Castro 2019: 225). Porén, a gran maioría da burguesía ilustrada non empregaba o galego nin na fala nin na escrita.
} 
sobre todo polo feito de escribir nunha lingua distinta do castelán ben asentado en España como única lingua nacional.

Para defender a nosa análise do Rexurdimento debemos entendelo coma un só corpo con distintas extremidades. En consecuencia, o preceptible sería falar de Rexurdimento literario para referirnos a este eido, como deberíamos falar de Rexurdimento musical cando tratamos os grandes compositores do nacionalismo musical galego da segunda metade do XIX (Marcial del Adalid, Xoán Montes, Pascual Veiga ou Chané)..$^{5}$

Por outra parte, adoptamos a perspectiva da «experiencia da subalternidade» enunciada por González-Millán. Este fenómeno determina as prácticas e expresións literarias así como a propia dinámica sociopolítica. Nas súas propias palabras (1994: 72), a experiencia da subalternidade afecta ao caso literario do seguinte xeito:

\begin{abstract}
Subdesenvolvemento de determinados rexistros literarios, a deficiente institucionalización social do discurso literario, o impacto da diglosia sociocultural e das condicións de dependencia económica e política, a multifuncionalidade do discurso literario, a subordinación institucional con respecto a outros sistemas literarios, as dificultades no proceso de recepción da producción literaria causadas polas mesmas condicións de subalternidade, a fixación temática das macrometáforas que obstaculizaron o desenvolvemento e a dinámica dos mundos imaxinarios utilizados nos diversos rexistros literarios, e finalmente, unha deficiente mobilidade xenérica, como exemplifica a privilexiada percepción da lírica, condicionada en parte por unha concepción esencialista da galeguidade.
\end{abstract}

En parte, esta experiencia está vencellada á conformación dos espazos e da opinión públicas. Pro, se comprendemos o Rexurdimento como unha expresión da estratexia de resistencia á uniformización, xerarquización e submisión do país galego (dende a economía á política, dende a cultura lato sensu até a literatura e lingua incluídas), debemos falar do contraespazo público e da produción do contradiscurso, dentro dun contexto complexo de «duplo patriotismo», en palabras de Josep Maria Fradera, que precisaría de máis matices do que este artigo nos permite. ${ }^{6}$

\footnotetext{
5 Para este apartado cultural é imprescindible a tese de doutoramento de Luís Costa, La formación del pensamiento musical nacionalista en Galicia hasta 1936 (Universidade de Santiago de Compostela, 2000).

6 En certa maneira, un repaso pola historia galega dende os Reis Católicos permite abesullar a existencia dunha actitude recorrente nas elites galaicas como era solicitar o recoñecemento por parte da Coroa (como expresión do poder político) dos logros e capacidades intelectuais do Reino de Galiza que contribuíran ao engrandecemento da monarquía española. Desta maneira, afirmando a «españolidade» do territorio queríase chamar a atención do inxusto abandono que vivía o país e provocar medidas reparadoras. A resposta negativa, ás veces incrementada en máis desprezo, facilitou un marco de reflexión en clave provincial oposto ao español que se manifestará con rotundidade durante o Rexurdimento.
} 
Por iso, a anotación anterior de Antón Figueroa é realmente pertinente cando estudamos o Rexurdimento: a escolla da lingua B no marco diglósico implicaba unha postura nítida con respecto á lingua ${ }^{7}$. A literatura tiña un poder extraliterario porque estaba conectada con tomas de posición políticas. Desta maneira, a renacenza acumula prácticas contrahexemónicas: a defensa, promoción e uso da escolla lingüística subalterna; a recuperación da memoria silenciada; a conformación de contraespazos públicos que «son focos de resistencia nos que se detecta o protagonismo de colectivos silenciados ou marxinados» e nos cales se crean «novas formas sociais e de reivindicación de representacións nacionais multisecularmente silenciadas» (González-Millán 2000: 64-65), co fin de restaurar e artellar unha identidade colectiva nacional... En consecuencia, os rexurdimentistas confrontan co habitus (en termos de Bourdieu) e marcan unha diferenza con outros autores galegos que optan unicamente polo campo literario español, na procura dun recoñecemento en Madrid dos pares, como farían Jacinto Salas y Quiroga, Antonio Neira de Mosquera ou Emilia Pardo Bazán, malia que os tres fosen de épocas distintas e mantivesen posicións diferentes con respecto aos fins do Rexurdimento.

Neste senso, é oportuno traer unha declaración de Nicomedes Pastor Díaz, realizada en 1846 en El Liceo da Coruña, durante un acto de «oficioso agradecemento» á súa mediación para evitar unha maior represión no contexto da Revolución de 1846: «Si Galicia pudo dejar de ser alguna vez mi patria política, era siempre mi patria literaria, porque era mi patria natural». Esta era unha opción de practicar esa dobre lealdade a Galiza e España. ${ }^{8}$

González-Millán (seguindo a Raymond Williams) detecta que os contraespazos públicos son expresións cruciais para a análise das prácticas políticas e culturais de movementos como o Rexurdimento, con deficiencias na institucionalización do discurso e sometidos á experiencia da subalternidade. Deste xeito, ábresenos un campo de análise realmente difícil pero profundamente revelador.

Un apartado clave para o estudo do Rexurdimento, dende a nosa visión, é o campo político en relación co campo cultural. A política toma da cultura elementos identitarios, o relato histórico nacional e a lingua como emblemas da diferencialidade nacional; é dicir, a cultura fornece de información, datos e argumentos pra crear un discurso político sobre a constitución histórica do

7 A escolla da lingua A supoñía o uso da lingua dominante nun campo literario no cal existía un prestixio sociocultural e unha potencial proxección na futura traxectoria do autor; a escolla da lingua B era a escolla da lingua dominada, carente de estruturas político-culturais, sen manuais lingüísticos, nun intento (por tanto, sen éxito asegurado) de conformar un campo literario que tiña unha fráxil tradición e un horizonte aínda máis incerto.

8 Pastor Díaz, autor destacado no romanticismo en castelán e figura política con capacidade de poder, deixounos dous poemas en galego. Ademais, foi chamado a prologar os Cantares gallegos de Rosalía, como estratexia da lexitimación dos poemas da muller escritora que apostaba por un libro monolingüe en galego, pro que a morte de Pastor Díaz impediu realizar. Vid. Ínsua López (2013). 
pobo galego. ${ }^{9}$ Pero á súa vez, a cultura usa o campo político como un espazo privilexiado de expresión, comunicación e proxección; é dicir, a creación cultural está ligada aos intereses políticos, aos intereses de construción dunha identidade nacional que permita conformar un campo cultural propio. Desta relación da cultura coa política é interesante a nota de Alonso Nogueira (1999: 578): «A inexistencia de institucións políticas propias forzou que a constitución do campo literario fose unha fase previa á constitución do campo político nacional». Unha reflexión que poderiamos combinar con esoutra de Habermas ao referirse á opinión pública literaria como precedente da opinión pública política.

De todos os xeitos, dentro da división metodolóxica que propón González-Millán (1995) cómpre subliñar a distinción entre o nacionalismo literario e a literatura nacional. A primeira amosa unha plena ensamblaxe do campo político co campo cultural. No caso da literatura, os textos (tanto en galego como en castelán) participan na creación do imaxinario nacional colectivo, nun contexto histórico europeo marcado pola construción das identidades, o romanticismo e os cambios políticoeconómicos propulsados polo liberalismo. ${ }^{10}$ Polo tanto, a intelligentsia do país aprópiase dos textos que son útiles ao proxecto político-cultural rexurdimentista, restando así autonomía ao campo literario e reducindo o interese na calidade literaria: non importaba que fose boa literatura senón que a literatura fose útil ao Rexurdimento.

A literatura desenvolveu un rol esencial na produción do imaxinario nacional colectivo, de aceptarmos a perspectiva construtivista da nación. ${ }^{11} \mathrm{O}$ discurso e as prácticas literarias contribuíron a crear, divulgar e consolidar unha idea de Galiza. Por exemplo, reparemos na pegada do celtismo á hora de edificar un mito fundacional, heroico e magnánime, e como rematou por consolidarse incluso nos propios símbolos actuais como o himno oficial, que é un poema de Eduardo Pondal musicado por Pascual Veiga onde se reitera a chamada á espertar do sono «pobo de Breogán», o caudillo celta que dominou o territorio galego e propiciou a invasión de Irlanda (tal e como conta a lenda do Lebor Gabála Érenn ou Libro das invasións, un dos volumes centrais da literatura medieval irlandesa datado no século XII).

9 Manuel Murguía é o paradigma do que falamos. Dende a súa faceta de historiador e impulsor cultural, pon a disposición todo o coñecemento para redactar unha voluminosa Historia de Galicia, que inicia a súa publicación en 1865 cunha radical definición de Galiza como nación. Neste sentido, o catedrático da USC en Ciencia Política Ramón Maiz escribe: «A aparición en 1865 do volumen I da Historia de Galicia, de Manuel M. Murguía, supuxo un decisivo punto de ruptura na traxectoria político-ideolóxica do pensamento galeguista. (...) Procedíase por vez primeira, e con toda radicalidade, á construcción histórico-teórica de Galicia como nación» (1999: 5). A teoría nacional que aplica Murguía parte dunha vertente voluntarista, tomada de Mancini, e dunha étnica, recollida dos autores alemáns, sobre a base de pensamento democrático-progresista.

10 Traemos aquí esta cita trasladable ao caso galego: «Fue el 'nuevo mundo' del liberalismo y del capitalismo, el nuevo Estado y la nueva imagen de la 'nación española', las nuevas prácticas políticas y culturales, lo que en definitiva condicionó decisivamente la formación de una identidad catalana diferenciada de la que oficialmente se divulgaba» Borja de Riquer (2001: 22).

11 Vid. Even-Zohar (1994).

SCRIPTA, Revista internacional de literatura i cultura medieval i moderna, núm. 15 / juny 2020 / pp. 85 - 114 ISSN: 2340-4841 · doi:10.7203/SCRIPTA.15.17556 
Todo isto explícase porque a cultura funciona como institución social, con capacidade de cohesión e depósito do imaxinario nacional colectivo. No caso singular da literatura, é, por tanto, un elemento central no repertorio da construción identitaria e da memoria discursiva. Ademais, reforzarase este valor conforme se outorgue á lingua unha alta representación da identidade. ${ }^{12} \mathrm{E}$, en definitiva, se a alma da nación é a lingua, esta definirá o Rexurdimento literario.

Parécenos moi atinada a reflexión que Manuel Jorba (1998) fai para o caso catalán e que resulta aproveitable para o caso galego:

\begin{abstract}
El moviment de la Renaixença no és el resultat d'un vacil.lant creixement de l'ús, sobretot poétic, de la llengua catalana i que, per tant, la valoració quantitativa i qualitativa de les obres en llengua catalana, els vint anys anteriors als Jocs Florals, ha de ser una dada imprescindible per contrastar-la amb la dels decennis anteriors a la consolidació del romanticisme a Catalunya $\mathrm{i}$ de les conseqüències que ha tingut en les formes i en els termes, però no un factor causal principal ni únic de la Renaixença. Té, en canvi, més transcendència el coneixement de les condicions socials i culturals de tota mena que fan possible el canvi d'actitud, immediat o tardà segons els individus, que efectivament es va produir dins la societat catalana respect a la pròpia cultura i a les institucions culturals, escolars, històriques, jurídiques, politioadministratives etc., inclosa, òbivament, la llengua, la seva consideració i el seu ús social, oral i escrit, diglòssic encara en el millor dels casos.
\end{abstract}

\title{
3. Trazos definitorios do Rexurdimento
}

O Rexurdimento é un movemento cívico que acumula unha continuidade de prácticas sociopolíticas e culturais, fronte á idea dos cortes limpos na historia, que se expande por todo o século XIX. Unha parte reducida da elite intelectual da burguesía liberal (xornalistas, letrados, boticarios, médicos...) liderou este proceso que non se recluíu a un único lugar senón que tivo expresións (intercomunicadas a través da prensa) nas principais urbes galegas. Para alén disto, é salientable o espazo de encontro que significou Santiago de Compostela posto que alí estaba a única universidade galega.

O obxectivo primeiro do Rexurdimento era converter o estigma en estima: lingua, costumes, paisaxes, tradicións populares, monumentos, persoeiros históricos, historia política... Con isto pretendíase rehabilitar o país (de aí o uso frecuente doutros termos semellantes ao Rexurdimento: rehabilitación, regeneración, renacimiento... $)^{13}$ ante o propio pobo galego pero tamén ante os ollos foráneos, onde se

12 Este valor da lingua, e da cultura en xeral, é perceptible noutros pobos europeos con idénticos procesos ao galego, como demostra Thiesse (2010).

13 O termo Rexurdimento usouse de maneira serodia, timidamente a partir do primeiro terzo do século XX e, sobre todo, a partir dos estudos dos anos 80 da pasada centuria. Por outra parte, convén subliñar o significado do prefixo re-, xa que esta é precisamente a idea central dos rexurdimentistas. Non se trataba de crear un marco político-cultural $e x$ novo para Galiza, senón recuperar o status en que viviu nos períodos de esplendor, que identificaron fundamentalmente

SCRIPTA, Revista internacional de literatura i cultura medieval i moderna, núm. 15 / juny 2020 / pp. 85 - 114 ISSN: 2340-4841 · doi:10.7203/SCRIPTA.15.17556 
difundía unha verdadeira lenda negra sobre a realidade do país galaico. Neira de Mosquera, nome clave para entender a conexión entre as dúas xeracións fundamentais do Rexurdimento, escribía esta impresión ao chegar a Madrid en 1843: «Galicia era entonces una especie de país primitivo; casi salvaje; se creía a medias su existencia (...). Bien es verdad que pocas y muy contadas eran las personas que atravesaban la pintoresca sierra del Cebrero» (Pintos 1967: 32). ${ }^{14}$

Un caso representativo da percepción negativa de Galiza, entre outros que poderiamos citar, é a contestación rexurdimentista ao tópico da paisaxe vista coma agreste, ruda, violenta e indecente. Así, Fermín Caballero (escritor, xornalista e deputado progresista) escribiu: «á la abundancia de lluvias, que ha sugerido á los poetas el apellidar á Galicia el orinal de España» (1864: 39, a cursiva é nosa). Fronte a isto aparece, por citar un caso, o prólogo de Rosalía de Castro a Cantares gallegos onde se louva o potencial paisaxístico en clara sintonía coas teses románticas. O proemio de Cantares é un verdadeiro manifesto político-cultural do Rexurdimento, e sob esa luz debe ser interpretado e non unicamente coma unha declaración estética.

Outra forma de retrucar as voces ofensivas e, á vez, impulsar a autoestima, é a aparición de libros con breves biografías de persoeiros de orixe galega destacados na historia española. Parécenos revelador desa necesidade que existía de restituír a memoria silenciada, nun marco de «duplo patriotismo», pero tamén de reprobar as actitudes que creaban e divulgaban a imaxe do pobo galego coma un cortello inmundo, como dixo Rosalía no referido prólogo, ou que negaba a capacidade intelectual da xente galega (lembremos o verso de Lope de Vega, "Galicia, nunca fértil en poetas»). Así, atopamos traballos desta tipoloxía en Vicente Turnes, Antonio Neira de Mosquera, Benito Vicetto, Teodosio Vesteiro Torres e Manuel Murguía.

Con todo, debemos estar atentos á conexión dos rexurdimentistas coas novas correntes europeas en materia político-económico e cultural. Se nos detemos na cuestión estética, cremos que a influencia do romanticismo é notable, de acordo coa opinión de María do Cebreiro (2011: 35): «A consideración de que a literatura é un tipo específico de pensamento (...) é unha conquista do romantismo europeo, e da súa teoría da imaxinación poética como forza intelectual revolucionaria. Este, e non outro, é o contexto estético e ideolóxico do Rexurdimento». Pola contra, esta hipótese é rexeitada por outros investigadores (Méndez Ferrín 1990; Angueira 2019) que consideran que o romanticismo nin foi decisivo nin foi definitorio.

coa época celta e sueva e, de xeito máis recente, coa Idade Media no tempo do arcebispo Xelmírez (século XII), que coincide co apoxeo do Camiño de Santiago, a radicación da monarquía no territorio galego (de feito o Panteón Real da Catedral de Santiago de Compostela acolle as tumbas de varios monarcas) e o período de ouro da literatura medieval galega ou literatura galego-portuguesa (sobre todo a lírica pero tamén a prosa). Pro esta recuperación do status non se presenta como unha volta ao modelo político antigo (como, en certa maneira, si pretenden os provincialistas vascos ou cataláns por medio dos foros), senón como un proceso de futuro guiado pola man do progreso e da liberdade.

14 Sobre a imaxe dos galegos na capital española, recomendamos a lectura do artigo «Los gallegos en Madrid», (La Ilustración Gallega y Asturiana, 13, 10-V-1879), de Augusto Mosquera. Aquí recóllese a frase de Mariano José de Larra: «El gallego (...) es un animal muy parecido al hombre, inventado para alivio del asno».

SCRIPTA, Revista internacional de literatura i cultura medieval i moderna, núm. 15 / juny 2020 / pp. 85 - 114 ISSN: 2340-4841 · doi:10.7203/SCRIPTA.15.17556 
$\mathrm{Na}$ nosa consideración, a recepción do romanticismo tivo importante eco na cultura galega. ${ }^{15}$ Así, un dos introdutores do romanticismo musical no Estado español foi o galego Marcial del Adalid (alumno de Moscheles en Londres), quen crearía a balada galega e publicaría o libro Cantares viejos y nuevos de Galicia (1877). No caso literario, apréciase a relevancia outorgada ás lendas de Ossian (as primeiras traducións ao castelán son obra do galego José Rúa Figueroa), o estudo de Fichte e Herder ou Mancini e Mazzini (dos cales beberá Manuel Murguía), a temática medieval (novelas de Neira de Mosquera ou Vicetto), o protagonismo do costumismo popular (a figura do gaiteiro) e da paisaxe na pintura (Serafín Avendaño ou Ovidio Murguía de Castro) ou a lectura atenta de autores románticos que inflúen na creación literaria de Rosalía, Pondal ou Aurelio Aguirre (Heine, Chateaubriand, Víctor Hugo, Leopardi) xa no ocaso romántico. Ademais, todo o proceso de recuperación da lingua, dos costumes ou cantares son produto do interese xerado polo romanticismo no propio e natural dun pobo, fronte ao modelo neoclasicista.

Igualmente, existía un interese crecente da burguesía galega, concentrada en urbes moi concretas (A Coruña, Ferrol ou Vigo), polas teses mercantilistas e a liberalización do mercado. A política económica do Estado español propiciou, por poñer tres exemplos, unha forte decadencia do sector téxtil do liño (que favoreceu o algodón en Cataluña), atrancos ao desenvolvemento da industria pesqueira (mediante o estanco do sal) ou a imposibilidade de comercializar certos produtos (millo ou trigo). Incluso a propia desamortización, no canto de favorecer o progreso e modernización industrial do agro, supuxo unha fortificación do foro, un modelo de contrato de herdanza medieval que resistiu até as masivas mobilizacións agraristas de inicios do XX que provocaron a aprobación da lei de redención foral (1926), en plena ditadura de Primo de Rivera.

Polo tanto, nese proxecto común que era o Rexurdimento existe, en materia económica, un predominio das teses liberalistas ou mercantilistas, que son as asumidas polo progresistas e republicanos de primeira onda. Así se percibe na prensa provincialista que adoita dedicar «artigos de fondo» a esta cuestión: a política económica ía contra Galiza. A solución, lemos en varios xornais, era a unión «del espíritu provincial».

En síntese, o Rexurdimento realiza unha operación de contención das aldraxes e tópicos, un posterior proceso de depuración e, por último, unha difusión en clave positiva dos elementos noutrora inxuriados. Por iso Justo Beramendi fala da «síndrome da aldraxe» para explicar a reacción rexurdimentista aínda que, na nosa opinión, as aldraxes explican parcialmente as motivacións da renacenza oitocentista.

Mailo fin último do Rexurdimento era global. O proceso depurador do estigma en estima era un pontón decisivo cara a un obxectivo último: tratábase de resituar Galiza, no seu conxunto e en todas as súas manifestacións, nun lugar esplendoroso que coincidise con aqueloutros (época celta, sueva e medieval) onde o poder político e cultural brillaron, como Manuel Murguía e outros

15 Unha aproximación ao conxunto do Estado español, vid. Romero Tobar (1994). 
historiadores decimonónicos galegos trataron de demostrar. E así, ás etapas de poder político propio correspondeulle, como resultado desa soberanía política, unha verdadeira explosión de riqueza cultural en materia escrita, musical ou pictórica (o exemplo é o medievo). Pola contra, o Rexurdimento fuxiu dunha mirada saudosista do pasado porque o propósito non é restituír un modelo político ou económico antergo (non se argumentan os dereitos históricos, nin as antigas leis locais), senón que a partir dos movementos democrático-progresistas, aos cales se incorporan de maneira activa, propóñense devolver Galiza a un status de poder político que incidirá no desenvolvemento material e intelectual do país. Por tanto, non é un movemento reaccionario senón claramente progresista. ${ }^{16}$

Por último, sostemos que a orixe do Rexurdimento non está nunha previa cosmovisión, produto dun longo e demorado debate entre un público ilustrado homoxéneo, senón na confluencia de prácticas dende a experiencia da subalternidade que, en varias ocasións, son o resultado da confluencia conflitiva coas forzas dominantes.

\section{Cronoloxía}

Durante os anos do actual milenio produciuse un frutífero traballo de recuperación de textos en galego do século XVIII e inicios do XIX. ${ }^{17}$ Estas descubertas provocaron unha revisión tanto da cronoloxía coma dos termos empregados pra este período literario. Na división tradicional, fálase dos «Séculos Escuros» (XVI-XVIII) como unha etapa de decadencia no uso escrito do galego.

Esta división sostíñase polo escaso coñecemento de textos escritos na lingua galega: apenas un feixe de páxinas de pouco valor literario. Pero, ao fío da exhumación de varios textos abriuse a reflexión sobre a adecuidade do termo. De aí que no primeiro volume da Historia da literatura galega (2013), de Xosé Ramón Pena, se substitúa a etiqueta de «Séculos Escuros» polo de «Galego Medio».

Efectivamente, a documentación recuperada permite soster a hipótese de que nunca houbo unha ruptura na práctica literaria en galego mais si, dentro das citadas circunstancias políticas, unha perda de aparellos de promoción cultural ou de protección lingüística como os existentes no

16 Debemos sinalar que houbo voces, por minoritarias que fosen, que fixeron outra lectura sobre a decadencia galega. Así, na cuestión da queda do uso do galego escrito e o proceso de substitución lingüística (perceptible na perda de calidade lingüística e a interferencia dos castellanismos), o gramático Saco Arce sinala como responsables destes feitos a modernidade e o progreso. A nivel político, esta tendencia conservadora representaríaa a fin de século o catedrático de Dereito Alfredo Brañas, que publica en Barcelona El regionalismo gallego (1889). Obra e escritor que influirían notablemente en Francesc Cambó, quen o definiu como o «apóstolo do rexionalismo». Curiosamente, Manuel Fraga (durante a súa presidencia na Xunta de Galiza) apropiarase da figura e pensamento de Brañas. En todo caso, Brañas e Saco Arce son a antítese da lectura histórica e política de Murguía (a dominante no Rexurdiento), quen está convencido que o futuro do país pasa polo progreso e non pola volta ao pasado.

17 Vid. Aneiros Díaz (2008) e Mariño Paz (2012).

SCRIPTA, Revista internacional de literatura i cultura medieval i moderna, núm. 15 / juny 2020 / pp. 85 - 114 ISSN: 2340-4841 · doi:10.7203/SCRIPTA.15.17556 
período medieval. Polo tanto, unha parte da elite ilustrada (aquela máis vencellada ao ámbito rural) ademais de falar galego de maneira cotiá tamén o usaba, de cando en vez, como lingua literaria. Lembremos que a intervención dos Reis Católicos supuxo unha derrota da nobreza galega que, como resultado, supuxo a entrega das propiedades patrimoniais á nobreza foránea, ademais doutras medidas aplicadas contra o reino que afectaban ao uso do galego na prosa notarial (substituído polo castelán), á administración de Xustiza (preferencia de funcionarios casteláns) ou á Igrexa (os mosteiros galegos pasaron a depender das congregacións castelás, por exemplo). ${ }^{18}$

É salientable ler este anaco da Historia de Galicia, de Álvarez Sotelo, escrita a finais do XVII e recollida por Ofelia Rey Castelao (2003: 70):

\begin{abstract}
No habiendo... precedido ni Concilio ni Cortes ni consentimiento uniforme de los gallegos, para actuar, otorgar, comerciar en lengua castellana... no los gallegos, sino los no gallegos que a los principios del siglo XVI inundaron el Reino de Galicia, no para cultivar sus tierras, sino para hacerse carne y sangre de las mejores, y para cargar con los más pingües empleos, así eclesiásticos como civiles... han introducido la monstruosidad de escribir en castellano. (...) Con esta ocasión se inundó Galicia de hombres no gallegos y castellanos: merinos, jueces, escribanos, curas de almas etc. eran provisiones de castellanos y apenas se daba algún empleo a gallegos naturales. Claro está que ninguno de esos empleos podría actuar en el idioma gallego, ni entender tampoco a lo actuado. Hermanos, sobrinos, primos, parientes, paisanos y criados de los presentes cargaban con todos los empleos y casi al mismo tiempo se introdujo la Audiencia en La Coruña y con eso se aumentó el número de los que en Galicia, ni hablaban ni entendían gallego y así se introdujo el abuso de escribir y actuar en castellano.
\end{abstract}

Sen dúbida, a peza máis importante deste preludio ao Rexurdimento literario son as Copras de Martín Sarmiento, escritas en galego en 1746 pero inéditas até $1859 ;{ }^{19}$ é dicir, publicadas xusto no Rexurdimento en edición dun dos poetas centrais, Xoán Manuel Pintos. O impacto desta obra de Sarmiento, ademais da súa voluminosa e notoria obra ilustrada, foi axiña reivindicada polos rexurdimentistas, en particular por Manuel Murguía e o grupo provincialista de Pontevedra.

Pro, alén disto, aparecen outros autores ilustrados preocupados tanto polo devir político-económico do reino galego (Sánchez Vaamonde pregoaba a necesidade de «adelantar y perfeccionar la Ilustración en el Reino de Galicia») como interesados na cultura propia. Dentro deste sentir constitúense dúas entidades liberais e ilustradas como foron a Real Sociedad Económica de Amigos del País de Santiago de Compostela (1784) e o Real Consulado na Coruña (1785), coa súa importante biblioteca aberta en

18 De feito, aínda no presente varios castelos pertencen a familiares nobiliarias foráneas, como a Casa de Alba que posúe a fortaleza do Castro Caldelas, o castelo de Moeche ou o de Andrade. Gerónimo Zurita (cronista da Coroa de Aragón no XVI) falou da «doma» de Galiza, e Vasco da Ponte (historiador galego do XV-XVI) de que «el rey Católico sojuzgó a Galicia». Vid. López Carreira (2016).

19 Esta obra, tamén coñecida como Coloquio de 24 gallegos rústicos, é vista como alicerce ou mesmo inicio do Rexurdimento (vid. Angueira, 2019: 215-250). 
1806. Importante tanto polos libros custodiados coma por ser centro de xuntanzas clandestinas da burguesía liberal e ilustrada coruñesa. ${ }^{20}$

En consecuencia, a entrada no século XIX produciuse nun contexto favorable á defensa dos intereses galegos e á promoción da cultura propia, aínda que a lingua non fose o elemento central nin a inquedanza máis decisiva para esta elite ilustrada. Porén, estábanse a dar unhas condicións que, coa entrada do romanticismo, prestaba maior atención a estes temas. De feito, o liberal exaltado Manuel Pardo de Andrade (considerado o fundador do xornalismo galego), era coñecedor a finais do XVIII da estética romántica (que el defende nos debates en Diario de Madrid fronte aos neoclasicistas) e escribiu unha notable e moi divulgada obra en galego, Os rogos d'un gallego establecido en Londres (1813), que coñeceu unha segunda edición en 1841. En ambos casos, xusto cando o liberalismo gobernaba en España.

Nós sostemos que o Rexurdimento comeza en 1808, ano da loita contra a ocupación francesa. A defensa desta datación facémola tendo en conta o cambio nas prácticas sociopolíticas, xa irreversible malia os atrancos postos polos poderes reaccionarios, que se producen no contexto da guerra e das Cortes de Cádiz. Referímonos, pois, á regulación de novas praxes liberais recollidas na Constitución de 1812; á constitución con poderes lexislativos e executivos da Junta Suprema del Reino de Galicia, que permitiu ordenar a loita contra os franceses pero tamén exercer o control sobre o país a todos os niveis, ${ }^{21}$ a aparición da prensa galega (liberal e absolutista) e a práctica, como resultado do paulatino ingreso na modernidade, da lectura pública en prazas e cafés dos textos xornalísticos ou follas voandeiras (moitas delas en lingua galega); a proliferación de escritos en galego que supuxo unha fixación do idioma na escrita e unha valorización do seu uso como canle de comunicación; a creación de círculos sociais semipúblicos (sobre todo da burguesía liberal: boticas, imprentas...); ou o propio exercicio de revisión da crenza na capacidade e valía do propio pobo co que isto supoñía a nivel de toma de conciencia, por moi iniciatática e nebulosa que fose.

No ámbito da literatura deste período encontrámonos coas Proezas de Galicia (1810), escritas en galego por José Fernández Neira. Nelas nárranse as batallas contras os franceses a partir dun diálogo entre dous labregos (Chinto e Mingote) que combateron o invasor. O curioso, pra o caso que nos ocupa, é que o libro explicita que candos os franceses foron expulsados de Galiza, o exército galego xa cumprira co seu cometido, deixando que a guerra continuase no territorio de Castela. Eran entendidas como entes territoriais diferenciados.

20 Vencellado ao Consulado estaba o parladoiro liberal do Café de La Esperanza, que sería un foco de pensamento revolucionario e da aparición da prensa liberal. Sería vítima posterior da represión absolutista.

21 Este órgano, existente dende antes pero sen facultades políticas máis que as de asesoramento á monarquía, representou o poder nacional durante o tempo en que o resto de España continuaba ocupada. A xunta recibía tratamento de alteza, posuía garda propia, formaba ante a bandeira, realizaba un protocolo e parafernalia previa ás xuntanzas, cada provincia (das sete antigas que existía) tiñan cadanseu representante... E todo isto dentro dun esquema realmente innovador posto que a Junta Suprema del Reino de Galicia erguíase, en construción piramidal, a partir das xuntas locais. Para máis info, vid. Barreiro Fernández (2009). 
Dentro do Rexurdimento podemos fixar tres etapas: precursores (1808-1856), Rexurdimento pleno (1857-1885), continuadores (1886-1906). ${ }^{22}$ Non nos deteremos na análise de cada unha delas e só indicaremos, groso modo, algúns datos.

Precursores: é unha fase marcada polo avance do sistema liberal. O seu asentamento permitiu a aparición de espazos formais de sociabilidade político-cultural entre os cales destacarán, pola súa matriz provincialista, a Academia Literaria (fundada en 1841) e El Liceo de la Juventud (fundada en 1847). A aprobación da lei de prensa e de liberdade de opinión permitiu que aparecese o xornalismo claramente provincialista que terá relativa continuidade e estabilidade. Ademais, politicamente esta etapa estará marcada a lume e ferro pola Revolución de 1846 e os Mártires de Carral, que co tempo se converterán en símbolos da loita provincialista deica as últimas consecuencias.

Rexurdimento pleno: acáelle este nome se temos en conta o enorme impulso vivido no eido cultural, coa convocatoria dos Xogos Florais na Coruña e en Pontevedra en 1861, a publicación das primeiras escolmas literarias (El Álbum de El Miño, 1858; El Álbum de la Caridad, 1862), a difusión de varios estudos lingüísticos (gramaticais e lexicográficos) ou o espertar do Rexurdimento musical. No eido político, a Década Moderada implicou que os provincialistas se refuxiasen fundamentalmente na prensa pero sen desentenderse da política no eixo progresista (así moitos provincialistas integraranse nas xuntas revolucionarias xurdidas da Gloriosa de 1868). A prensa provincialista consolídase e aparecen os primeiros cabezallos monolingües en galego ( $O$ Vello do Pico Sagro ou O Tío Marcos da Portela) e saen libros coma Cantares gallegos (1863) e Follas novas (1880) de Rosalía de Castro, ou Aires da miña terra (1880), de Curros Enríquez.

Continuadores: marcada pola morte de Rosalía (1885) que deveu nunha pugna pola apropiación da súa obra como se testemuñou nun acto simbólico de enorme transcedencia para a cultura galega: a velada necrolóxica por Rosalía celebrada en setembro de 1885 na Coruña coa participación de Emilia Pardo Bazán e Emilio Castelar pro coa sinalada ausencia do viúvo, Manuel Murguía, desconforme cos propósitos políticos, culturais e lingüísticos da convocatoria. Esta etapa publicitará a tensión político-cultural do nacente rexionalismo (aparecido tras a frustrada República de 1873), que se expresará de maneira rotunda na tensión de campo acontecida entre o modelo de Manuel Murguía (progresista e nacionalista) e o de Emilia Pardo Bazán (conservador e folclorista). ${ }^{23}$ Politicamente, malia as debilidades orgánicas, xorde a primeira organización política propia sen distinción ideolóxica (Asociación Regionalista Gallega, que acolle dende posicións procarlistas até os republicanos de esquerdas). No eido literario continúa a produción en lingua galega, agora diversificada a outros xéneros (teatro, por exemplo). Finalmente, esta será unha fase marcada pola implicación dos sectores nacionalistas na emigración que propiciarán, por exemplo, a aparición da

22 O termo precursores está tomado dunha obra de Manuel Murguía, Los precursores (1886), que é un exercicio de fixación da memoria discursiva. En canto a continuadores, empregámola por ser unha obra pensada polo propio Murguía pro que nunca saíu á luz.

23 Vid. Martínez González (2020).

SCRIPTA, Revista internacional de literatura i cultura medieval i moderna, núm. 15 / juny 2020 / pp. 85 - 114 ISSN: 2340-4841 · doi:10.7203/SCRIPTA.15.17556 
bandeira e o himno galegos pro, sobre todo, pularán pola creación da Academia Galega (1906), que será a primeira institución cultural e lingüística con capacidade de institucionalización do discurso rexurdimentista.

\section{A función da lingua}

A función desempeñada pola lingua, nos procesos de creación das identidades nacionais, é central. A recepción das ideas románticas sobre materia lingüística, sobre todo procedentes de Herder e Fichte, terán especial atención en Galiza. Para termos unha idea do valor que se lle outorga ao idioma, citemos Fichte: «non son os homes quen forman as linguas, senón que é a lingua a que os forma a eles». Pola súa parte, Herder defendían que a lingua era o «núcleo inaccesible»e unha manifestación do «íntimo tono vital».

$\mathrm{Na}$ onda de expansión romántica dáselle unha enorme atención ás linguas naturais (natusprache) na medida en que son resultado orixinal, xenuíno e espontáneo da creación popular. Por tanto, non son linguas construídas por mentes ilustradas nin elementos artificiais senón produto dunha comunidade histórica que radica nun espazo xeográfico concreto. De aquí procede a explosión filolóxica da que fala Benedict Anderson. Herder, en obras coma Ensaio sobre a orixe da linguaxe (1772) ou en Metacrítica (1799), explicita que a lingua natural é a representación da alma dun pobo. ${ }^{24}$ E, precisamente, os románticos procuran definir o volksgeist.

Manuel Murguía recibe esta influencia en idade temperá. Desta maneira, cando aínda residía no Madrid do Bienio Liberal, elabora un ensaio por entregas en La Oliva (1856-57), ${ }^{25}$ o xornal rexurdimentista de Vigo protexido polos republicanos progresistas, e complementado con outro traballo en El Museo Universal (1858), ${ }^{26}$ para tratar o tema cultural galego. ${ }^{27}$

Nestes escritos elabora unha tese, infrecuente na época, para determinar que constitúe e que non constitúe a literatura galega. Para termos unha idea xeral, fronte ás propostas que delimitaban a literatura dun pobo a que esa fose espello do volksgeist e non exclusivamente a lingua en que estivese escrita (mírese a historia da literatura de Amador de los Ríos de 1861, por exemplo), Manuel Murguía defende a aplicación do criterio filolóxico, como xa antes fixera Antonio Neira de Mosquera nun artigo do ano 1841.

24 Vid. Safranski (2009).

25 «De las diversas causas que han influido de una manera desfavorable en el desarrollo de nuestra literatura provincial» e «Del poeta de Galicia».

26 «Poesía gallega contemporánea».

27 De maneira máis detallada, vid. Martínez González (2017).

SCRIPTA, Revista internacional de literatura i cultura medieval i moderna, núm. 15 / juny 2020 / pp. 85 - 114 ISSN: 2340-4841 $\cdot$ doi:10.7203/SCRIPTA.15.17556 
A fixación do criterio filolóxico como nomos do campo literario (seguindo a Bourdieu) tardou en consolidarse. A explicación dánola o propio Murguía no citado traballo: a escasa produción literaria en galego coñecida en 1855 (case nada se sabía da literatura medieval galega) débese compensar coa produción cultural dos rexurdimentistas. É dicir, unha das tarefas comúns é a escritura en galego. Ademais tiñan por diante o obxectivo de demostrar que o galego era unha lingua conformada como tal, de orixe nobre e valía pra calquera eido, ${ }^{28}$ non un dialecto no significado contemporáneo, ${ }^{29}$ ao cal lle era negado a súa pertinencia no tratamento de determinados temas. ${ }^{30}$

Entón, mentres se crea literatura en galego, que tarefa marca Murguía para demostrar a existencia dunha cultura propia e que razóns se deron para que non se escribise antes na súa lingua natural? Pois, sinxelamente, desmontar un dos tópicos recorrentes, xa citados, contra Galiza: a carencia intelectual dos galegos, vistos apenas coma brazos de traballo e números da emigración. Desta maneira, Murguía e outros autores explican a conformación étnica do pobo galego que atopa unha forma de manifestación por medio da cultura e da lingua. Esta conformación histórica ten dúas fontes matriciais: os celtas e os suevos. ${ }^{31}$ Eles son a base identitaria de Galiza e, ao ser pobos distintos dos que ocuparon o resto peninsular, propiciaron unha cultura distinta á española. En consecuencia, Murguía decreta que ao ser pobos con formación histórica e expresión cultural propia (resultado desa historia), existe un volksgeist galego distinto do español e, conforme á «normativa» romántica, o éxito da cultura galega estará no seu reencontro co volksgeist, afastándose da cultura

28 Como indica Anderson (1993: 111), seguindo Seton-Watson, as linguas europeas non oficiais esfórzanse por demostrar a súa utilidade para calquera xénero. Así sucede coa obra de György Bessenyei para a lingua húngara.

29 Os rexurdimentistas usan con frecuencia o termo «dialecto» para referirse ao galego pro non co senso pexorativo actual, senón como comprensión do galego como unha lingua sen normativización nin codificación, carente de gramáticas e dicionarios. De feito, será no Rexurdimento cando se inicien estes traballos lingüísticos con notables resultados.

30 É interesante o debate aberto na prensa a raíz da publicación das Poesías (1878) do crego e gramático Juan Antonio Saco Arce (autor da primeira gramática galega). Así, parte da crítica literaria galega penaliza os poemas en castelán, por seren imitacións da poesía de Santa Teresa ou Frei Luís de León, mentres que gaban os poemas relixiosos en galego porque era unha temática inexplorada nesta lingua. Pola contra, Emilia Pardo Bazán manterá unha visión totalmente oposta: aplaude a poesía en castelán pro desbota a poesía relixiosa en galego, con argumentos deste teor: «No ocultaré cuán infructuosas -aunque loables- me parecen las tentativas de desarollar temas abstractos y de las gigantes proporciones del salmo Miserere, en el dialecto gallego, mas a propósito para la nota concreta, viva, pintoresca, sentida á veces, ingénua y natural siempre, y popular en suma». Ademais, engade, a comparativa coa literatura en catalán, á cal si lle outorga esa capacidade que ao galego nega. Lembremos as importantes relacións da Condesa Pardo Bazán con destacados intelectuais cataláns, como Narcís Oller ou Josep Ixart. Máis info, en Martínez González (2018).

31 Ambos pobos ligados ás culturas nórdicas e ás razas arias, asunto relevante cando en Europa se discutía a superioridade das culturas do norte sobre as do sur. E así, os rexurdimentistas incorpóranse a este discurso mediante o cal se a formación histórica do pobo galego está nos celtas e nos suevos, mentres que o resto peninsular recibe as bases semíticas e árabes, resulta que a cultura galega é diferente desta e, ademais, superior. Non por isto, os rexurdimentistas (Murguía, como teórico, á cabeza) sostiñan a superioridade da raza celta sobre outras, aínda que si existan puntualmente citas sobre este asunto. Pro o pensamento democrático-progresista vivo no Rexurdimento subordinaba estes argumentos a outros de maior peso. 
española por non ser nin propia, nin natural, nin expresión íntima do pobo galego. En resumo, os rexurdimentistas testemuñan historicamente a existencia dun «xenio nacional» e, con isto, logran unha mudanza discursiva crucial para o Rexurdimento.

Poñamos algúns anacos dos textos murguianos para decatarnos da radicalidade da tese: «perdida su memoria [a galega] entre el inmenso fárrago y la balumba de otra literatura diferente [española] por ser diferentes sus sentimientos, y diversa su índole y la fuente de sus impresionres». Noutra parte, engade: «Por eso, nuestros poetas que debían ser tanto no son nada; por eso nuestra literatura es tan escasa, pues el desaliento sorprendió á muchos que luchaban en vano por seguir un camino cerrado para ellos»; é dicir, pechado porque non antendía ao seu verdadeiro «espírito nacional». Murguía pregunta aos lectores: «نHallais acaso algún punto de contacto entre este pueblo y el nuestro, entre estas costumbres y las nuestras, entre estos sentimientos y los nuestros? No, ciertamente». E remata arengando a prol de «la poesía que sólo hay aquí, la poesía que sólo se entiende aquí, la poesía que nace sólo para aquí».

O modelo literario, por tanto, non pode sero español («no es, ni puede servir de norma á nuestra poesía, diferente de ella en un todo», insiste Murguía). Por iso, atraveso do celtismo, os rexurdimentistas engarzan coas culturas nórdicas de Irlanda e Escocia, á súa vez pobos con identidade propia e sometidos ao poder centralista de Londres. ${ }^{32}$ Desta maneira, os autores de referencia serán Walter Scott (para prosa), Ossian e Thomas Moore (para poesía) e Daniel O’Conell (para política).

Ana Belén Fortes, autora de Manuel Murguia e a cultura galega, recompilou as seguintes oposicións entre a cultura galega e a española a partir dos traballos do polígrafo nacionalista: fondo/forma, espontaneidade/artificio, sentimento/imaxinación, tristeza e melancolía/optimismo e arrogancia, suavidade e dozura/aspereza e dureza, poesía subxectiva/poesía obxectiva e o uso da métrica nacional galega (2000: 82-87). ${ }^{33}$

Esta exposición de Murguía compleméntase cos traballos de historia política, tamén publicados en La Oliva. ${ }^{34}$ Neles describe unha historia étnica que se asenta, como escribimos antes, nos celtas e nos suevos. Posteriormente, chegaría a Idade Media con Xelmírez coma gran figura, de enorme poder político e relixioso. Estes tres períodos (celtas, suevos, Idade Media) coinciden con época de soberanía política para o reino galego. Mais cando se produza a entrada dos Reis Católicos, no contexto posterior ás revoltas irmandiñas, se inicia o deterioro: «la centralización (...) hizo cada vez

32 As referencias a Irlanda e a loita pola súa independencia serán recorrentes (no político e no cultural) no nacionalismo galego dende o século XIX até o presente.

33 Estas oposicións teñen un precedente en Antolín Faraldo, o líder provincialista da revolta de 1846 e figura admirada por Murguía. A profesora Ríos Panisse (1993: 158-159) analiza o traballo «Nuestra bandera literaria», publicado en El Porvenir (1845), destacando estas oposicións: atlantismo/mediterraneísmo, xermanismo/latinismo, europeísmo/ africanismo, idealismo romántico historicista/pragmatismo clásico.

34 «De la historia de Galicia» e «Resumen de la historia política de Galicia».

SCRIPTA, Revista internacional de literatura i cultura medieval i moderna, núm. 15 / juny 2020 / pp. 85 - 114 ISSN: 2340-4841 · doi:10.7203/SCRIPTA.15.17556 
más pobre y escasa nuestra historia política». E será coas «sabias y liberales ideas de la enciclopedia» (nótese aquí a lectura progresista da conformación histórica de Galiza) que se detiveron as aldraxes e deprezos ao país.

Pero, en todo caso, o interesante para noso traballo é constatar que Murguía afirma que as épocas de poder político resultaron as épocas de esplendor cultural. Polo tanto, cando Galiza volte posuír poder político, volverán ter esplendor cultural.

En todo este esquema, a lingua ocupa o espazo central porque, como miramos, é representación da creación popular, do seu espírito nacional. Así, sitúase nun dos elementos de maior representatividade pública da formación nacional de Galiza. Ademais, conclúese que o galego é un romance formado a partir das orixinarias linguas celtas, latín e linguas xermánicas (que, filoloxicamente, é certo). Deste xeito, a lingua é a representación da nación e quen mellor a domine será tamén quen mellor represente literariamente o «espírito nacional». Noutros termos: quen domine a lingua ocupará unha posición de privilexio dentro do campo de poder..$^{35} \mathrm{O}$ escritor, seguindo o modelo do bardo ossiánico (que en certa maneira emulará Eduardo Pondal durante a segunda metade do XIX), é o cantor do pobo: costumes, cantigas, música, tradicións, traxes, paisaxe... e tamén é a voz da patria por se libertar. O escritor ten a capaciade de interpretar e representar a voz popular, precisamente, porque coñece a súa alma. Desta maneira, o escritor que aspire a isto debe adoptar a lingua desa comunidade que, no noso caso é o galego. Só deste xeito, segundo os rexurdimentistas, pódese expresar o sentimento natural e expresar a alma do pobo: a lingua é o sangue da nación, ou como escribiría Saco Arce (seguindo a Herder), a lingua é a alma da nación.

Saco Arce (Perez Ballesteros 1878: XI) describiuno así:

\begin{abstract}
No se ocultaba á su penetración que nada contribuye tan eficazmente á mantener vivo el carácter nacional, á fortalecer el espíritu de independencia y á estrechar los vínculos de raza, como el amor que se profesa al patrio idioma. Y este amor es tanto más fuerte, cuanto mayor sea el brillo que el idioma reciba de numerosas e importantes obras literarias que lo avaloren y realcen á los ojos del pueblo, de suerte que pueda legítimamente enorgullecerse de hablarlo.
\end{abstract}

En definitiva, Murguía marca un obxectivo futuro (a produción literaria en galego que permita establecer o criterio filolóxico como norma do campo literario emerxente ou en construción), explica a xénese do «xenio nacional» ou do volksgeist a partir da historia política e cultural (que lle permite, por un lado, establecer as diferenzas entre a cultura galega e a española pero tamén remarcar a relación entre os campos político e cultural) e define o modelo de escritor nacional.

Contra o último cuarto do século XIX, tras a divulgación dos cancioneiros medievais e a produción

35 A canonización do escritor rexurdimentista realízase sob o criterio do dominio e coñecemento do galego, non pola súa calidade literaria. De aí a positiva recepción, entre os rexurdimentistas, dos poemas galegos de Saco Arce.

SCRIPTA, Revista internacional de literatura i cultura medieval i moderna, núm. 15 / juny 2020 / pp. 85 - 114 ISSN: 2340-4841 ·doi:10.7203/SCRIPTA.15.17556 
literaria rexurdimentista, publícanse tres obras nas cales se aplica o criterio filolóxico: Historia crítica de la literatura gallega (1887), de Augusto Besada; Resume da historia de Galicia (1899), de Florencio Vaamonde; e La literatura gallega en el siglo XIX (1903), de Eugenio Carré Aldao. Por tanto, datamos nesta altura das postrimerías do Rexurdimento, a aceptación do criterio filolóxico como nomos do campo literario.

Por tanto, o factor lingüístico non é algo connatural á nación, un elemento permanente e constitutivo per se. En troques, trátase da operación interpretativa que determinados axentes realizan sobre o idioma para que se este se torne nun trazo delimitador da nación. A lingua, e a literatura en galego, aparece como como peza da construción identitaria na medida en que un grupo de persoas lle outorgan ese valor e desenvolven unha posición teórico-política a partir da aceptación de que a lingua é unha creación da comunidade nacional.

\section{A historia nacional}

Tamén nos debemos referir ao impulso romántico de redactar as historias nacionais, do cal o Rexurdimento non quedou á marxe. Neste sentido, houbo un monumental pulo para redactar a historia galega con parámetros propios pero marcadamente historicistas, onde se define dende bases étnicas o suxeito protagónico (o pobo galego) e, por ende, produce unha cesura coa historia oficial española. Sobre todo en determinadas etapas e, sobre todo, en determinadas interpretacións dos sucesos acontecidos (por exemplo, o caso dos Reis Católicos, vistos pola historiografía española como os pacificadores do reino galego, tras as intensas revoltas irmandiñas, verdadeira revolución social avant la lettre, pero analizados pola historiografía galega como o inicio da decadencia do poder galego por mor do centralismo monárquico).

A historia serviu de fonte nutritiva e determinante para a composición do relato nacional, da macrometáfora nacional, da redacción dunha memoria discursiva da nación. Pro tamén valeu como base de creación literaria, como se constata no citado caso do celtismo ou no interese medievalista (en consonancia coa voga romántica). Así, Benito Vicetto acadaría unha enorme popularidade (dentro e fóra de Galiza) por novelas ambientadas no medievo. Unha delas, Los hidalgos de Monforte, chegou a coñecer numerosas edicións en vida do autor e foi reproducida en diversa prensa española como folletín.

Con respecto á Idade Media, debemos advertir que os rexurdimentistas de primeira hora non coñecían a valiosísima tradición da literatura medieval galega ou literatura galego-portuguesa. ${ }^{36}$ O universo das cantigas reducíase apenas a poucos textos de Rodríguez del Padrón e Macías o Namorado. Existía a sospeita dunha maior produción literaria medieval grazas ao estudo do frade Martín Sarmiento (ilustrado de metade do XVIII e pai da Filoloxía Galega) que exhumara un texto

36 Vid. López (1991).

SCRIPTA, Revista internacional de literatura i cultura medieval i moderna, núm. 15 / juny 2020 / pp. 85 - 114 ISSN: 2340-4841 · doi:10.7203/SCRIPTA.15.17556 
do Marqués de Santillana no cal se afirma que o galego era a lingua literaria. ${ }^{37}$ Por iso, Manuel Murguía describe á súa xeración (Xeración do 56) ante «unha verdadera noche literaria». Será no tramo final do Rexurdimento cando se divulgue a produción dos cancioneiros galegos a partir da obra xornalística de Teodosio Vesteiro Torres e, sobre todo, dos tomos d'El idioma gallego (1886), de Antonio De la Iglesia.

A publicación en 1838 da Historia de Galicia, de José Verea e Aguiar (liberal ilustrado), será o punto de partida da expansión da temática celtista e a afirmación da orixe étnica do pobo galego. Este libro, definido por Neira de Mosquera como un «monumento levantado para restaurar nuestra nacionalidad», será un manual de formación da Xeración do 46, a primeira netamente provincialista.

A partir de aquí aparecerán outros libros historiográficos, como o de Leopoldo Martínez Padín ou a monumental historia de Benito Vicetto, pero haberá un proxecto que será referencial: a Historia de Galicia (1865-1913) de Manuel Murguía. Os catros historiadores románticos coincidirán ao sinalar o elemento celta como o fundacional.

Murguía apuntará, en todo caso, que a identidade galega formouse dende a base celta e coa achega xermánica traída polos suevos. Isto permitía xunguir Galiza cos países nórdicos e coa raza aria, sendo estes asuntos de grande interese nese tempo. É revelador como Murguía resta importancia á romanización de Galiza posto que supón un elemento distorsionador na súa hipótese de formación aria da identidade. En todo caso, subliñemos que Murguía encaixa esta tese da formación étnica galega cunha teorización nacional tomada de Mancini e dunha articulación voluntarístico-nacional; é dicir, que a tese nacionalista non descansa só nunha lectura orgánica da nación nin realiza unha interpretación xenófoba das etnias (Maiz, 1999).

En todo caso, a tarefa historiográfica do Rexurdimento implicou a recuperación da memoria silenciada que, en realidade, conformou unha parte notable de contradiscurso xa que cuestionou e se arredou do relato oficial. Asemade, non esquezamos que nestes exercicios historiográficos se realizan dende enfoques ideolóxicos que propician operacións de exclusión e inclusión, o que Raymond Williams denominou a «tradición selectiva».

37 «368 E despues fallaron esta Arte, que Mayor se llama, et el Arte comun, creo que en los Reynos de Galicia, é de Portugal, donde no es de dubdar, que el exercicio de estas ciencias, mas que en ningunas otras Regiones, et Provincias de la España, se acostumbró; en tanto grado, que no há mucho tiempo, cualesquier Decidores, ó Trobadores de estas partes, agora fuesen Castellanos, Andaluces, ó de la Estremadura, todas sus obras componian en Lengua Gallega, ó Portuguesa. 369 Acuérdome (dice), Señor muy magnífico, siendo yo en edad no proveta, mas asaz pequeño mozo, en poder de mi abuela Doña Mencía de Cisneros, entre otros libros haber visto un gran volumen de Canticas Serranas, Decires Portugueses, y Gallegos; cuyas obras aquellos que las leían loaban de envenciones sotiles, é graciosas, y dulces palabras. Habia en otras de Juan Suarez de Pavía, el qual se dice haber muerto en Galicia por amores de una Infanta de Portugal. E de otro Fernan Gonzalez de Senabria». Vid. Memoria para la historia de la poesia y poetas españoles (1775: 154). 


\section{Progresismo e provincialismo}

No ocaso do século XVIII, o ilustrado coruñés José Cornide (destacado xeógrafo, naturalista e escritor bilingüe) laiábase do abandono que padecía Galiza por parte da monarquía. Un abandono continuado «porque quieren que Galicia sea país de Indias», escribía en 1774. É dicir, Cornide denuncia o maltrato que sufrían sectores como a pesca, que se sometía aos intereses dunha burguesía catalá que atraca a finais do XVIII na costa galega, sobre todo nas Rías Baixas, disposta a aplicar métodos agresivos de explotación pesqueira que acabarían por esquilmar as rías. ${ }^{38}$ Por tanto, xa na Ilustración galega aparecen cavilacións deste tipo (case todas de orde económica) arredor do progreso e defensa de Galiza pro no marco da existencia do Reino e do seu órgano representativo, por moi baleirado que este estivese de competencias e actuase apenas como órgano asesor da Coroa.

O debate sobre a cuestión nacional ou territorial do Estado español evidénciase durante as sesións das Cortes de Cádiz e mediante o fenómeno do juntismo aparecido no contexto da guerra contra a ocupación francesa. ${ }^{39}$ Nesta dirección, Portillo Valdés (2000) destaca o artigo 11 da Constitución de 1812 («Se hará una división más conveniente del territorio español por una ley constitucional») que xera a reacción do catalán Felipe Arner ou do valencián Javier Borrull, contrarios á imposición deste modelo sen ter en conta os dereitos dos territorios. Mais aquí está a cerna do debate: o dereito histórico ou foral está por riba da vontade da nación representada nas Cortes de Cádiz?

Ademais, a cuestión das colonias de Ultramar apuntalan unha disxuntiva que era de obrigada resolución: que dereitos político-administrativos terán os territorios de América e que encaixe se fará deles na nova nación española?

O provincialismo, como termo e significado, ocupa un espazo do debate constitucional neste arranque do XIX. Así, na prensa galega trátase o provincialismo nas mesmas coordenadas ideolóxicas que se fan en Cádiz: oposición por parte dos sectores liberais e apoio por parte dos sectores moderados. ${ }^{40}$ En todo caso, queremos constatar que a cuestión provincialista é recepcionada nos círculos intelectuais galegos. ${ }^{41}$

38 Portillo Valdés (2018) lembra, de maneira oportuna, o carácter nacional da Ilustración fronte á idea xeneralizada de tomala só coma un «fenómeno universalista y al margen del nacionalismo».

39 A cuestión do juntismo é moi relevante tanto para a constitución da Junta Suprema del Reino de Galicia como pola experiencia política que supuxo para amplos sectores sociais, na medida en que as xuntas eran órganos electos de representación política. Sobre o caso galego, malia centrarse no límite de dúas provincias (Mondoñedo e Lugo), é revelador a investigación de Veiga Fandiño (2017). Unha lectura sobre a evolución das juntas de defensa e a relación coas deputacións, vid. Estrada Sánchez (2008).

40 Así se recolle nas páxinas d’El Ciudadano por la Constitución (liberal) e en Estafeta de Santiago (absolutista).

41 No Diario de Operaciones del Sexto Cuerpo del Ejército (1811) critícase a existencia de certo «provincialismo» galego. Dez anos despois, o xornal El Ciudadano (10-III-1821), órgano do liberalismo coruñés, lemos: «El espíritu del provincialismo que la ignorancia y un mal entendido interés o un error perjudicial a la mutua unión e ilustración nacional han extendido

SCRIPTA, Revista internacional de literatura i cultura medieval i moderna, núm. 15 / juny 2020 / pp. 85 - 114 ISSN: 2340-4841 $\cdot$ doi:10.7203/SCRIPTA.15.17556 
Posteriormente (1835-1843), como indica Segarra i Estarelles (2005), as posicións provincialistas xiraron dende o ámbito conservador ao progresista. A defensa da autonomía das cidades (onde estaba o poder político do Partido Progresista) e do modelo descentralizado do estado confrontouse, como alternativa política, ao modelo de estado centralista e autoritario imposto polos moderados dende o Goberno (Estrada Sánchez 2008). Mais, como se comproba en estudos recentes, o provincialismo non pretendía abrir un relato conflitivo en canto á conformación da nación española senón, máis ben, contribuír á constitución efectiva da nación española dende unha mirada máis diversa e plural.

O provincialismo galego emerxe no espazo público durante a Rexencia de Espartero, como resultado dun fermento anterior localizado na Ilustración galega e en determinados círculos liberais (pensemos no caso de Pedro Boado Sánchez) ${ }^{42}$ que protagonizan a loita contra os franceses ou o triunfo constitucional que dá paso ao Trienio. O provincialismo dos anos 40 (Xeración do 46) faise patente a través da prensa e de sociedades coma Academia Literaria de Santiago de Compostela. ${ }^{43}$ De maneira maioritaria sitúase, no eixo ideolóxico, no lado progresista. Figuras coma Antolín Faraldo, Antonio Romero Ortiz ou José Rúa Figueroa (que terán destacados papeis en Madrid tras o exilio interno logo da represión exercida en Galiza en 1848) son exemplos desta tendencia. ${ }^{44}$

O provincialismo, dentro da moderna historiografía galega, explícase como «unha tendencia intelectual-política que xorde no seo do liberalismo español e que comeza a xerar lentamente un corpus de ideas parcialmente diferenciado» (Beramendi 2007: 73). Estas ideas recóllense nunha lectura política do pasado histórico, na denuncia do desprezo padecido, na demanda de medidas ante o atraso endémico en materia de infraestruturas ou modernización industrial, na crítica ao

y conservado entre nosotros. Galicia es una de las provincias de España en que más domina este apego».

42 Boado lideraba a Junta de Defensa y Armamento en Monforte de Lemos cando propón a creación dunha Junta Suprema de Galicia con plenos poderes soberanos que sería resultado dunha federación das xuntas comarcais. Osuna Rey (2006: 32) afirma: «en la misma junta de Monforte, aparece la figura de Pedro Boado, que encabezó un movimiento independentista de Galicia, en vista de que a su juicio era débil la resistencia que las provincias españolas hacían a las tropas de Napoleón». Boado, educado nas ideas revolucionarias de 1789, é autor do texto en galego, malia o título en castelán, Diálogo entre dos labradores gallegos afligidos y un abogado instruido, despreocupado y compasivo (1823). Sobre Boado, vid. Navaza (2018). Sobre os liberais galegos, vid. Barreiro Fernández (1982).

43 É interesante anotar, só como cita, que o xeneral Martín José Iriarte (home do círculo próximo ao xeneral Espartero), apadriñou o nacemento da Academia Literaria en 1841, verdadeiro cenáculo do provincialismo político-cultural galego en Santiago de Compostela e que funcionou como lugar de instrución alternativo á universidade compostelá. Ademais, Eduardo Ruiz Pons (líder dos republicanos, perseguido e morto no exilio) e Eduardo Chao (outro líder do Partido Demócrata que ocuparía postos relevantes na historia do republicanismo español) eran familia de Rosalía de Castro e protectores de escritores coma Aurelio Aguirre ou o propio Manuel Murguía.

44 Os tres (Faraldo, Romero e Rúa) redactaron o xornal El Porvenir (1845), de acento provincialista e abeirado ás ideas libertarias. É interesante o manifesto «Nuestra bandera literaria», publicado nos dous últimos números antes de ser vítima da censura, así como o apadriñamento feito polo coruñés Ramón De la Sagra dende París, onde participaba con Proudhon en proxectos sociais como o Banco do Pobo. 
abandono secular... Un corpus político non estruturado pro que presenta publicamente os epígrafes dun programa á espera de ser redactado con traballos teóricos e académicos.

Pola súa parte, Xosé Ramón Barreiro Fernández (o máximo especialista na cuestión e, en xeral, de todo o século XIX galego), indica que o termo «provincialismo» procedía da reivindicación da unidade do Reino de Galiza, desartellado en 1833 (tras aprobarse a proposta de división territorial de Xavier de Burgos) e que reducía as sete antigas provincias galegas ás catro actuais. Aquilo supoñía liquidar, por unha parte, a histórica configuración territorial do reino galego e, ademais, a desaparición dun órgano político propio que, por moi baleirado de competencias non deixaba de manter un poder simbólico que floreceu durante a francesada, con soberanía propia (en ausencia do rei) que lle permitiu establecer tratados internacionais con Inglaterra e Portugal, organizar a administración interna do reino e convocar asembleas na Coruña para a toma de decisións de aplicación na terra galega. De todo isto eran conscientes os provincialistas, como indica Artaza (1993: 144):

\footnotetext{
Una serie de políticos y historiadores gallegos opuestos al modelo centralista del nuevo Estado liberal comenzaron a difundir una imagen muy favorable de la Junta: la historia de unha corporación «popular»y «democrática», defensora de los intereses del Reino ante el monarca y sus ministros, que probaba la existencia de un territorio diferente dentro de la Corona de Castilla con cierta capacidad de autogobierno desde, al menos, principios de la Edad Moderna.
}

Mais, na nosa opinión, convén matizar que o provincialismo galego non se debe concibir como un movemento que nace a partir da división territorial de 1833 senón que era un pensamento vivo na realidade política e cultural das elites ilustradas galegas anterior a este ano. É dicir, a intelligentsia galega está en conexión e sabe do debate territorial que sucede nas Cortes de Cádiz (pensemos no compostelán Benito Ramón Hermida), como despois será coñecedor das posturas presentadas por provincialistas coma Vicente Boix e, sobre todo, Víctor Balaguer que manterá unha estreita e duradeira relación co provincialismo progresista galego dende a década dos 40: dende Antolín Faraldo (líder civil da Revolución de 1846) até Rosalía de Castro (a quen traducirá dous poemas de Cantares gallegos ao catalán no seu libro Esperansas i recorts). ${ }^{45}$

O provincialismo de inicios do XIX ligábase a un particularismo cultural (idioma incluído) e territorial vencellado á existencia dos reinos integrados na Coroa. O provincialismo galego, como xa anotamos en anteriores páxinas, constrúe a súa macrometáfora nacional. Crea o imaxinario nacional colectivo, sitúa os elementos fundamentais do carácter nacional (etnia, idioma, pasado político...) e introduce esta lectura provincialista dentro dos canles do progresismo político organizado. De aí a súa relevancia, como elemento cívico-político (por tanto, non militar), durante a Revolución

45 É significativo o cruce de cartas entre Balaguer e Ventura Ruiz Aguilera onde tratan o libro Cantares gallegos. Ruiz Aguilera recrimina dous poemas de Rosalía («Castellanos de Castilla» e «A gaita gallega») por consideralos ofensivos a Castela, pro serán precisamente eses dous os poemas que Balaguer decide traducir ao catalán e incluír no citado libro. 
de 1846. Antolín Faralado, secretario da Junta Provisional del Gobierno de Galicia (formada por civís) redacta o manifesto oficial con cargado fervor provincialista, de inicio a fin, e do cal podemos extractar este anaco: ${ }^{46}$

\begin{abstract}
El pueblo conquistará en esta revolución lo que le han arrebatado los cómicos de los pronunciamientos: PAN Y DERECHOS. Galicia, arrastrando hasta aquí una existencia oprobiosa, convertida en una verdadera colonia de la Corte, va a levantarse de su humillación y abatimiento. Esta Junta, amiga sincera del país, se consagrará constantemente a engrandecer el antigueo reino de Galicia, dando provechosa dirección a los numerosos elementos que atesora en su seno, levantando los cimientos de un porvenir de gloria. Para conseguirlo es esforzará constantemente en fomentar intereses materiales, crear costumbres públicas, abrir las fuentes naturales de su riqueza, decrépita fundada sobre la ignorancia. Despertando el poderoso sentimiento del provincialismo, y encaminando a un solo fin todos los talentos y todos los esfuerzos, llegará a conquistar Galicia la influencia de que es merecedora, colocándose en el alto lugar que está llamado el antiguo reino de los suevos.
\end{abstract}

O manifesto foi publicado polo órgano da Junta titulado La Revolución. Saía impreso no obradoiro da familia Compañel. E foi, precisamente, Juan Compañel quen imprimirá as primeiras obras de Rosalía de Castro (como Cantares gallegos) ou de Manuel Murguía en Vigo, onde mantiña unha imprenta e dirixía o xornal La Oliva e El Miño, dous títulos centrais do Rexurdimento.

Por tanto, o discurso provincialista toma forma pública durante 1840-1845 e é militarmente derrotado en 1846, que supuxo o fusilamento dos mandos militares (Mártires de Carral), o exilio dos mandos civís (Inglaterra e Portugal) e a prisión e desterro doutras persoas militantes no progresismo.

Pro isto non implicou a desaparición das ideas provincialistas. En 1847, xusto no día do primeiro aniversario dos fusilamentos de Carral (non hai casualidade!) fúndase El Liceo de la Juventud, espazo de sociabilidade formal para a Xeración do 56 na cal están Rosalía, Murguía, Pondal, Paz Novoa e outros grandes nomes do Rexurdimento político-cultural. Recupérase a prensa provincialista a partir de 1850 da man de Antonio Neira de Mosquera, quen actúa de conector entre a Xeración do 46 coa do 56, ao ser membro activo da Academia Literaria e agora d'El Liceo de la Juventud, impulsor da celebración dos Xogos Florais e do uso do galego, novelista medieval e investigador da historia galega.

Neira dirixe El Eco de Galicia (1851-52) sostendo o lema Galicia ante todo e con expresos chamados provincialistas como «Somos gallegos» ou «Deseamos organizar de nuevo el provincialismo gallego». Así, no artigo titulado precisamente «El provincialismo gallego» (1851) expón todos os obxectivos políticos, económicos e culturais deste pensamento. ${ }^{47}$ En síntese, a reclamación dun

46 Sobre a Revolución de 1846 é fundamental a obra de Barreiro Fernández (1977).

47 Vid. Neira de Mosquera (2017).

SCRIPTA, Revista internacional de literatura i cultura medieval i moderna, núm. 15 / juny 2020 / pp. 85 - 114 ISSN: 2340-4841 · doi:10.7203/SCRIPTA.15.17556 
discurso propio para pular polos intereses galegos que superase as rivalidades ideolóxicas e que antepuxese o progreso material e intelectual de Galiza.

Os rexurdimentistas participan activamente neste espazo. Todos se movían na vontade de colaborar na construción do imaxinario nacional colectivo. Hai un esforzo por fornecer o pobo galego de material que dignificase a súa existencia, identidade e promovese a recuperación do status de dignidade e poder do desaparecido reino. Até en certo punto, podemos adiviñar unha planificación, redactada por Manuel Murguía á hora de intervir na nacente esfera pública nacional. Así apareceron publicacións vencelladas á gramática ou á lexicografía galega, libros de historia que marcan as diferenzas coa historia española, coleccións de cantares e músicas populares, volumes de biografías selectas de persoeiros galegos notables, o xurdir da prensa de compromiso provincialista (posta ao servizo da defensa dos intereses galegos de toda tipoloxía: economía, política, cultura, historia...) ou a a defensa da liña sostida polo sector máis avanzado do Partido Progresista, favorable ao entendemento co Partido Demócrata.

Emilia Pardo Bazán (1888: 38-39), oposta a esta liña rexurdimentista, aproveita o contexto da velada necrolóxica dedicada a Rosalía de Castro en 1885 pra espetar esta recriminación ao Rexurdimento:

\footnotetext{
Si estas quejas no son mero juego retórico; si, como es de creer expresan una aspiración sincera, contenida en el movimiento intelectual de Galicia, tenemos que reconocer que el renacimiento lleva en sí un germen de separatismo, germen poco desarrollado todavía, pero cuya presencia es imposible negar, y acaso sea el único fruto político y social de este florecimiento poético. Qué otra cosa significa la frecuente confusión del concepto de patria con el de tierra ó región nativa, confusión que aquí se repite tan á menudo en el lenguaje hablado y escrito!
}

Estas palabras de Pardo Bazán constatan, por un lado, o impacto do Rexurdimento no círculo letrado galego; polo outro, o peso político na produción cultural. Estas palabras, lembremos, foron ditadas ante Emilio Castelar (quen presidía a velada) quen prologara Follas novas de Rosalía, xusto un dos libros criticados por Emilia Pardo Bazán. Dentro do contexto político de tensión co rexionalismo, Castelar aceptará estas críticas da Condesa renegando do escrito cinco anos antes. Igualmente, Emilia Pardo Bazán opina que o tratamento de «lingua» para o «dialecto galego» era parte dun proceso político, ao que amosa unha rotunda e activa oposición.

Un pouco despois, en retrospectiva, Aureliano Pereira (dirixente republicano federal que pasara a representar o rexionalismo máis progresista) lembraba como foran recollidas as propostas provincialistas: «En 1878, en Galicia, y en unión de mi querido amigo el eximio periodista Alfredo Vicenti, mantuve los principios de lo que hoy se llama regionalismo y entonces era provincialismo, rudamente combatido por la prensa de la Corte, atribuyéndonos como el programa ¡Guerra a Madrid! que así tradujeron siempre, los recelos y egoísmos de la centralización el ¡Viva Galicia!»».

48 Vid. El regionalismo y la poesía gallega (1895). 


\title{
9. A prensa rexurdimentista
}

Non queremos pechar este artigo sen reivindicar a función do xornalismo rexurdimentista. A prensa galega comezou a andar a inicios do XIX, no contexto da guerra contra os franceses, pero será durante a Rexencia de Espartero (1840-43) cando se produza un fenómeno excepcional como foi a proliferación de cabeceiras xornalísticas de liña provincialista e, maioritariamente, de tendencia progresista. Foi un feito extraordinario se pensamos na escasa tradición xornalística galega e, por suposto, a inexistencia (agás citas puntuais) dun discurso escrito que xirase arredor da demostración da identidade propia de Galiza en termos expresamente políticos. Unha reclamación que, en boa medida, vén provocada pola reforma territorial de Xavier de Burgos en 1833, que supuxo a desaparición formal e oficial do Reino de Galiza ao ano seguinte. A carón disto aparece o incuestionable impacto da tese celtista promovida por Verea Aguiar en 1838 e o influxo do romanticismo que animou a publicación de traballos costumistas, históricos ou lingüísticos nesa dirección de fixar a identidade, o volksgeist ou o xenio nacional. Disto derivábase que Galiza se constituíra historicamente como un territorio, pobo e cultura diferente do resto do Estado español.

O catedrático de literatura da Universidade da Coruña, Xosé María Dobarro (2000: 97), destaca:

\begin{abstract}
A importancia extraordinaria que nestes momentos adquire a prensa periódica constitúe unha das dimensións fundamentais deste proceso de recuperación da dignidade no que estaban empeñados os precursores. Débese ter en conta que, a falta doutros medios de incidencia social, estes intelectuais utilizan como tribuna os órganos de expresión que nacen ó abeiro dos faladoiros, das sociedades culturais e, máis tarde, das organizacións políticas que proclaman, defenden e reivindican os valores de Galicia.
\end{abstract}

Exactamente, a prensa desenvolveu unha actividade fundamental para favorecer a consecución dos obxectivos rexurdimentistas. Ademais, no período de aparición da esfera e opinión públicas foi importante que neste xurdir houbese unha notable presenza do pensamento provincialista na medida en que condicionaba o debate, a información e propiciaba un discurso (case sempre progresista) sobre os retos que Galiza tiña por diante. ${ }^{49}$ Basta ler El Idólatra de Galicia (1841-1842), El Eco de Galicia (1850-1851), La Oliva (1856-1857), El Miño (1857-1868), Revista Galaica (18741876), O Tío Marcos da Portela (1876-89), La Ilustración Gallega y Asturiana (1878-1882), El Regional (1884-1893), Galicia. Revista Regional (1887-1893) ou Revista Gallega (1895-1907) para constatalo.

Ademais, a prensa galega na emigración comezará a ocupar un espazo representativo na esfera pública galega: El Eco de Galicia da Habana (1878-1902), ElEco de Galicia de Bos Aires (1892-1926), A Gaita Gallega (1885-1889) ou La Tierra Gallega (1894-1896). O esforzo migratorio que repercutía no país (fundación de escolas, granxas de capacitación agraria, sociedades labregas e obreiras,

49 Nunha análise máis ampla cumpriría comprender estas publicacións como parte de construción do contradiscurso e da conformación do contraespazo público. 
mercados de abasto...) mirábase reforzado pola autoridade institucional dos seus centros galegos (por exemplo, os poderosos da Habana ou Bos Aires) e pola contribución á cultura do país. ${ }^{50}$

O apartado literario da prensa foi un espazo aberto ás colaboracións que tivesen, polo xeral, temática galega (en castelán ou en galego). Aparecen novelas ou ensaios por entregas, inclúense innumerables poesías e dáse conta da actividade sociocultural do país. Pro ademais, debemos valorar a prensa como un espazo de «sociabilidade virtual» como ten apuntado Andreas Gelz (2009: 173).

\footnotetext{
Ya no se trata aquí solamente de un equivalente imaginario de la tertulia en el sentido de unos lectores que pueden imaginarse sumergidos, a través de la lectura, en una tertulia imaginaria entre ellos y los redactores del periódico. En este caso, se va mucho más lejos: a través del proceso público de lectura estimulado por el autor -la lectura en voz alta para la servidumbrese establece una nueva forma de sociabilidad; el órgano de prensa sirve en cierto modo como vehículo de un impulso social, una función que el periódico toma a su cargo junto a la de la transmisión de información.
}

Certamente, esta tese anotada por Gelz resulta estimulativa para a investigación da prensa. Desta maneira, reitérase a necesidade de concibir o xornal como obxecto de estudo e non só como un bebedeiro informativo. O xornal é outro elemento con capacidade de intervención social, política e cultural. A prensa é o cuarto poder, como dixera Edmund Burke na Cámara dos Comúns en 1787. E como tal poder debe ser incluído na investigación oitocentista.

50 Follas novas (1880), de Rosalía, foi publicado grazas á Sociedade de Beneficencia dos Naturais de Galicia na Habana, e foi editado precisamente nesta urbe. O Centro Galego da capital cubana desenvolvería máis accións a prol da cultura galega até o seu devalar na segunda metade do XX. 


\section{Bibliografía}

Alonso Nogueira, A. (1999) «A invención do escritor nacional. Rosalía de Castro, a poeta e a súa patria» en Álvarez, R. \& Vilavedra, D. (eds) Cinguidos por unha arela común. Homenaxe ó profesor Xesús Alonso Montero, Tomo II, Santiago de Compostela, Universidade de Santiago de Compostela, pp. 41-64.

—. (2009) «Caminos abandonados. La España Regional, sobre los contextos culturales del regionalismo» en Serrano Alonso, J. \& De Juan Bolufer, A. (coords.) Congreso internacional literatura hispánica y prensa periódica, 1875-1931, Santiago de Compostela, Universidade de Santiago de Compostela, pp. 87-99.

Álvarez, R. \& Angueira, A. \& Rábade Villar, M. \& Vilavedra, D. (coords.) (2014) Rosalía de Castro no século XXI. Unha nova ollada, Santiago de Compostela, Consello da Cultura Galega.

Anderson, B. (1993) Comunidades imaginadas, México, Fondo de Cultura Económica.

Aneiros, R. (coord.) (2008) Papés d'emprenta condenada. A escrita galega entre 1797 e 1846, Santiago de Compostela, Consello da Cultura Galega.

Artaza Montero, M. M. De (1993) «La Junta del Reino y la autonomía de Galicia», Obradoiro de Historia Moderna, 2, pp. 143-150.

Barreiro Fernández, X. R. (1979) El levantamiento de 1846 y el nacimiento del galleguismo, Santiago de Compostela, Pico Sacro.

—. (1982) Liberales y absolutistas en Galicia (1808-1833). Vigo, Edicións Xerais.

- - (2009) Historia social da Guerra da Independencia en Galicia, Vigo, Edicións Xerais.

—. (2012) Murguia, Vigo, Editorial Galaxia.

Beramendi, J. (2007) De provincia a nación, Vigo, Edicións Xerais.

Caballero, F. (1864) Fomento de la población rural, Madrid, Imprenta Nacional.

Castro, X. (2019) Servir era o pan do demo. Historia da vida cotiá en Galicia, Vigo, Editorial Galaxia.

Cebreiro, M. do (2011) Fogar impronuncibale. Poesía e pantasma, Vigo, Editorial Galaxia.

Dobarro Paz, X. M. ${ }^{a}$ (2000) «O nacemento dunha literatura», en Tarrío, A. (coord.) Galicia. Literatura. Os Séculos Escuros. O século XIX, A Coruña, Hércules de Ediciones.

Domingo, J. M. (2009) «Renaixença. El mot i la idea», Anuari Verdaguer, 17, pp. 215-234.

Estrada Sánchez, M. (2008) « ¿Y para qué queremos las diputaciones? Una reflexión en torno a los orígenes y primera evolución de las diputaciones provinciales», Anuario da Facultade de Dereito da Universidade da Coruña, 12, pp. 303-319.

Even-Zohar, I. (1994) «La función de la literatura en la creación de las naciones de Europa» en Villanueva, D. (ed.), Avances en teoría de la literatura: estética de la recepción, pragmática, teoría empirica y teoría de los polisistemas, Compostela, Universidade de Santiago de Compostela, pp. 357-377. 
Figueroa, A. (1988) Diglosia e texto, Vigo, Edicións Xerais.

—. (2001) Nación, literatura, identidade, Vigo, Edicións Xerais.

Fortes, A. B. (2000) Manuel Murguía e a cultura galega, Santiago de Compostela, Sotelo Blanco Edicións.

Fradera, J. M.' (2003) Cultura nacional en una sociedad dividida, Madrid, Marcial Pons.

Gelz, A. (2009) «Prensa y tertulia: interferencias mediales en la España del siglo XVIII», Olivar. Revista de literatura y cultura españolas, 13, pp. 165-200.

González-Millán, X. (1995) «Do nacionalismo literario a unha literatura nacional. Hipóteses de traballo para un estudio institucional da literatura galega», Anuario de Estudios Literarios Galegos, pp. 67-81.

—. (2000) Resistencia cultura e diferencia histórica, Compostela, Sotelo Blanco Edicións.

Guillamet, J. (2008) «El estudio de los periódicos y la historia propia del periodismo», en Aneiros, R. \& Pérez Pena, M. S., A comunicación no seu tempo, Santiago de Compostela. Consello da Cultura Galega, pp. 29-33.

Hermida, C. (1992) Osprecursores da normalización. Defensa e reivindicación da lingua galega no Rexurdimento (1840-1891), Vigo, Edicións Xerais.

Ínsua López, E. M. (2013) «Encadramento e singularidade de Nicomedes Pastor Díaz na literatura galega do seu tempo», en Barreiro Fernández, X. R. (coord.) O resplandor primeiro. Estudos en homenaxe a Nicomedes Pastor Díar, A Coruña, Real Academia Galega.

Jorba, M. (1998) «Els correntes provincialistes i la Renaixença», en Maninchedda, P. (coord.), La Sardegna e la presenza catalana nel Mediterraneo, Caligari, Cooperativa Universitaria Editrice Calgiaritana, pp. 92-113.

López, T. (1991): Névoas de antano. Eco dos cancioeiros galego-portugueses no século XIX, Santiago de Compostela, Laiovento.

López Carreira, A. (2016) «O Reino de Galicia no remate da Idade Media», en Mariño Paz, R. (ed.), A lingua galega no solpor medieval, Santiago de Compostela, Consello da Cultura Galega.

Lourido, I. (2014) História literaria e conflito cultural, Santiago de Compostela, Laiovento.

Mariño Paz, X. R. (ed.) (2012) Papés d'emprenta condenada (II). Lingua galega e comunicación nos inicios da Idade Contemporánea, Santiago de Compostela, Consello da Cultura Galega.

Martínez González, X. (2014) «Rosalía de Castro: a ponte entre o Rexurdimento e a Renaixença», eHumanista/VTTRA, 5, pp. 170-189.

—. (2015) «Renaixença e Rexurdimento. Unha proposta comparativa», Anuari Verdaguer, 23, pp. 279-292.

—. (2017) «Do xenio nacional ó criterio filolóxico. Algúns apuntamentos sobre a literatura galega no Rexurdimento», Follas Novas, 2, pp. 66-95.

- (2018): «A obra de Saco arce no contexto do Rexurdimento», Boletín da Real Academia Galega, 379, pp. 419-462.

SCRIPTA, Revista internacional de literatura i cultura medieval i moderna, núm. 15 / juny 2020 / pp. 85 - 114 ISSN: 2340-4841 · doi:10.7203/SCRIPTA.15.17556 
Méndez Ferrín, X. L (1990) De Pondal a Novoneyra. Poesía galega posterior á guerra civil, Vigo, Edicións Xerais.

Monteagudo, H. (1999) Historia social da lingua galega, Vigo, Editorial Galaxia.

Navaza, G. (2018) «Noticia e reivindicación de Pedro Boado», en Acuña, A. \& Costas, X.-H. \& Iglesias, A. (coords.) Homenaxe a Ramón Gutiérrę Izquierdo, Vigo, Universidade de Vigo, pp. 177195.

Neira de Mosquera, A. (2017) Galicia ante todo. Páxinas esquecidas do Rexurdimento (1840-1853), edición de X. Martínez González, Santiago de Compostela, Alvarellos Editora.

Osuna Rey, J. M. (2006) Los franceses en Galicia. Historia militar de la guerra de independencia en Galicia (1809), A Coruña, Fundación Pedro Barrié de la Maza.

Pardo Bazán, E. (1888) De mi tierra, A Coruña, Tipografía de la Casa de Misericordia.

Pena, X. R. (2013) Historia da literatura galega. Das orixes a 1853, Vigo, Edicións Xerais.

Pérez Ballestero, J. (1878) Versos en dialecto gallego y correspondencia de sus principales voces, Madrid, P. Calleja y Compañía.

Pintos, S. (1967) Neira de Mosquera y su obra, Memoria de licenciatura, Madrid, Universidad de Madrid.

Portillo Valdés, J. M. ${ }^{a}$ (2000) «Federalismo y nación en los orígenes del liberalismo español», Araucaria, 4, pp. 70-112.

—. (2018) «Ilustración, nación e imperio en la monarquía española», Araucaria, 40, pp. 59-73.

Rey Castelao, O. (2003) Libros y lectura en Galicia. Siglo XVI-XIX, Santiago de Compostela, Xunta de Galicia.

Ríos Panisse, M. ${ }^{a}$ do C. (1993) «Nuestra bandera literaria, de Antolín Faraldo. Primeiro manifesto artístico galeguista», Anuario de Estudios Literarios Galegos, 2, pp. 157-171.

Riquer, B. De (2001) Escolta Espanya. La cuestión catalana en la época liberal, Madrid, Marcial Pons.

Romero Tobar, L. (1944) Panorama crítico del romanticismo español, Madrid, Castalia.

Safranski, R. (2009) Romanticismo. Una odisea del espiritu alemán, Barcelona, Tusquets.

Segarra i Estarelles, J. R. (2005): «Liberalismo, historia y provincialismo en las décadas centrales del siglo XIX», en Sabio, A. \& Forcadell, C. (eds.), Las escalas del pasado. IV Congreso de Historia Local de Aragón, Huesca, Instituto de Estudios Altoaragoneses.æ

Tarrío, A. (2004) «Identidade literaria e referentes interliterarios. Algunhas consideracións a propósito da literatura galega», en Abuín González, A. \& Tarrío Varela, A. (eds.) Bases metodolóxicas para unha historia comparada das literaturas na Peninsula Ibérica, Compostela, Universidade de Santiago de Compostela, pp. 445-459. 
Xurxo Martínez González. Arredor do Rexurdimento. Apuntamentos xerais

Thiesse, A.-M. (2010) La creación de las identidades nacionales, Madrid, Ensenada de Ézaro.

Veiga Alonso, X. R. (2017) Poder e politica na Galiza vilega 1790-1833. Provincias de Lugo e Mondoñedo, Santiago de Compostela, Bolanda Ediciones.

SCRIPTA, Revista internacional de literatura i cultura medieval i moderna, núm. 15 / juny 2020 / pp. 85 - 114 ISSN: 2340-4841 $\cdot$ doi:10.7203/SCRIPTA.15.17556 